\title{
Kinetics of Microbial Respiration and Nitrogen Mineralization in Great Lakes Forests
}

\author{
Donald R. Zak, ${ }^{*}$ David F. Grigal, and Lewis F. Ohmanr
}

\begin{abstract}
Recent attention has focused on organic matter storage in forested ecosystems because climate change could potentially alter this process. Labile organic matter pools are especially important because they may be most strongly influenced by changes in soil temperature and water availability. We measured rates at which $\mathrm{C}$ and $\mathrm{N}$ were released from labile organic matter within the forest floor and mineral soil of jack pine (Pinus banksiana Lambert), red pine ( $P$. resinosa Aiton), balsam fir [Abies balsamea (L.) Miller], sugar maple (Acer saccharum Marshali), and quaking aspen (Populus tremuloides Michaux) forests. Forest floor and mineral soil samples were assayed for microbial respiration and $\mathrm{N}$ mineralization using a long-term ( 32 wk at $35^{\circ} \mathrm{C}$ ) laboratory incubation. Cumulative amounts of respired $\mathbf{C}$ and mineralized $\mathbf{N}$ were fit to first-order rate equations; pools and rate constants were compared among forests. Labile (respired) $\mathrm{C}$ pools in forest floor ranged from 67 (jack pine) to $92 \mathrm{~g} \mathrm{C} \mathrm{m}^{-2}$ (sugar maple), four to six times less than that measured in mineral soil. Rate constants for microbial respiration were statistically different among forest types, but means ranged narrowly in forest floor $\left(0.269-0.299 \mathrm{wk}^{-1}\right)$ and mineral soil $\left(0.303-0.350 w^{-1}\right)$. Labile (mineralized) $\mathrm{N}$ pools ranged from 2.2 (red pine) to $4.1 \mathrm{~g} \mathrm{~N} \mathrm{~m}^{-2}$ (sugar maple) in forest floor, an order of magnitude less than those in mineral soil. Rate constants for $\mathbf{N}$ mineralization varied from 0.326 to $0.556 \mathrm{wk}^{-1}$ in forest floor and from 0.043 to 0.069 wk $^{-1}$ in mineral soil. Regional climatic variables were weakly correlated with labile $C$ and $N$ pools and with rate constants. Annual in situ estimates of microbial respiration and $\mathrm{N}$ mineralization were far less than respired $C$ and mineralized $N$ pools, suggesting that only a fraction of labile soil organic matter is annually metabolized within these forests. Local climate, rather than the chemistry of labile organic matter, appears to be an important factor constraining the annual in situ flux of $\mathrm{C}$ and $\mathrm{N}$ from this pool.
\end{abstract}

$F^{\circ}$ OREST FLOOR and mineral soil represent significant pools of $\mathrm{C}$ and $\mathrm{N}$ within temperate forests, containing $\approx 60 \%$ of the $\mathrm{C}$ (Cole and Rapp, 1981; Birdsey, 1990; Grigal and Ohmann, 1992) and 95\% of the $\mathrm{N}$ capital (Cole and Rapp, 1981). Although a relatively large proportion of the $\mathrm{C}$ and $\mathrm{N}$ within temperate forests occurs in forest floor and surface mineral soil, only a small fraction of these pools are annually metabolized by soil microorganisms. For example, Raich and Nadelhoffer (1989) summarized soil respiration from a wide range of ecosystems and found fluxes from 250 to $1200 \mathrm{~g} \mathrm{C} \mathrm{m}^{-2} \mathrm{yr}^{-1}$ in temperate forests; others have reported a similar range (Raich and Schlesinger, 1992). These estimates, which include both root and microbial respiration, represent $\approx 2$ to $15 \%$ of the total $\mathrm{C}$ within the forest floor and surface mineral soil $\left(\approx 7000 \mathrm{~g} \mathrm{C} \mathrm{m}^{-2}\right)$. Billings et al. (1977) suggested that only $10 \%$ of the net flux of $\mathrm{CO}_{2}$ from tundra soils was from microbial respiration; the

D.R. Zak, School of Natural Resources and Environment, Univ. of Michigan, 430 E. University Ave., Ann Arbor, MI 481091115; D.F. Grigal, Dep. of Soil Science, Univ. of Minnesota, 1991 Upper Buford Circle, St. Paul, MN 55108; and L.F. Ohmann, U.S. Forest Service, North Central Forest Exp. Stn., Grand Rapids, MN 55744. Received 29 June 1992. *Corresponding author.

Published in Soil Sci. Soc. Am. J. 57:1100-1106 (1993). largest contribution arose from the respiration of vascular plant roots and rhizomes. In temperate forests, recent estimates suggest that microbial respiration may contribute to a much larger share $(\approx 30-70 \%)$ of soil respiration (Schlesinger, 1977; Ewel et al., 1987; Raich and Nadelhoffer, 1989; Raich and Schlesinger, 1992). Based on these estimates, $\approx 75$ to $890 \mathrm{~g} \mathrm{C} \mathrm{m}^{-2} \mathrm{yr}^{-1}$ could be released via microbial respiration, further suggesting that microbial metabolism annually consumes a relatively small proportion of soil $\mathrm{C}$.

The majority of soil $\mathrm{N}$ occurs in fractions that are long lived and resistant to microbial degradation (Smith and Paul, 1990). Ammonium- $\mathrm{N}$ is released from these relatively large pools through $\mathbf{N}$ mineralization. This process contributes a large proportion of $\mathrm{N}$ that is annually assimilated by the forest overstory, and rates can range from 2 to $12 \mathrm{~g} \mathrm{~N} \mathrm{~m}^{-2} \mathrm{yr}^{-1}$ among northern temperate forests (Nadelhoffer et al., 1983; Pastor et al., 1984; Plymale et al., 1987; Zak and Pregitzer, 1990; Zak et al., 1991; Zak and Grigal, 1991). Although net $\mathrm{N}$ mineralization is of fundamental importance in regulating the productivity of forested ecosystems (Keeney, 1980; Pastor et al., 1984; Zak et al., 1989) soil microbes liberate only $\approx 10 \%$ of all organically held $\mathrm{N}$ on an annual basis (calculated from Nadelhoffer et al., 1983; Pastor et al., 1984; Zak and Pregitzer, 1990; Zak et al., 1991; Zak and Grigal, 1991).

The storage and flux of $\mathrm{C}$ and $\mathrm{N}$ in forest floor and mineral soil has received considerable attention due to their link to ecosystem productivity, and recently because climate change has the potential to alter the cycling and retention of these elements within terrestrial ecosystems. Labile pools of organic matter within the soil are particularly important because they control ecosystem productivity in the short term, and could be the pools most affected by altered soil temperature and moisture regimes resulting from climate change. The objectives of our study were to: (i) determine the influence of regional climate and forest composition on the kinetics (i.e., substrate pools and rate constants) of microbial respiration and $\mathrm{N}$ mineralization in Great Lakes forests, and (ii) compare laboratorydetermined pools of labile $\mathrm{C}$ and $\mathrm{N}$ with published in situ estimates of annual microbial respiration and net $\mathbf{N}$ mineralization. We quantified and compared pools and rate constants for microbial respiration and $\mathrm{N}$ mineralization in the forest floor and mineral soil of five forest types that commonly occur throughout the upper Great Lakes region.

\section{MATERIALS AND METHODS}

\section{Study Sites and Sample Collection}

The forested stands we studied were dominated by jack pine $(n=38)$, red pine $(n=22)$, balsam fir $(n=22)$, sugar

Abbreviations: MAP, mean annual precipitation; MAT, mean annual temperature; AET, actual evapotranspiration; MSE, mean square error. 


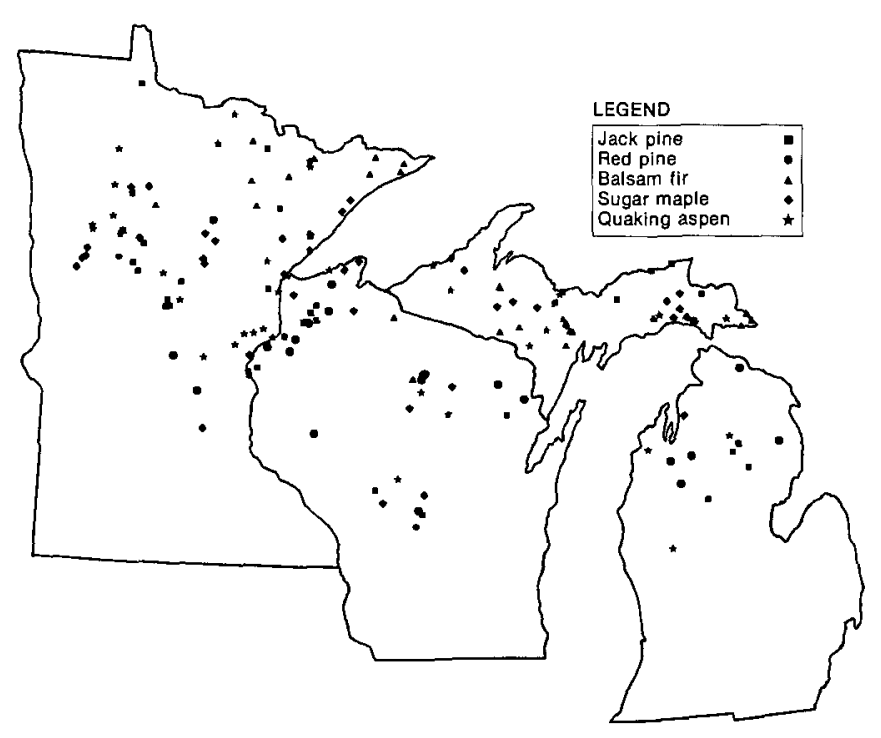

Fig. 1. Locations of 154 forested stands in the Upper Great Lakes region. Stands were dominated in the overstory by jack pine, red pine, balsam fir, sugar maple, and quaking aspen.

maple $(n=36)$, and quaking aspen $(n=36)$. Most red pine stands were plantations, whereas stands in the other forest types established naturally. Land use prior to plantation establishment is unknown. Stands representative of each forest type were replicated along a climatic and atmospheric deposition gradient extending southeast from Minnesota to Michigan's Lower Peninsula (Fig. 1). These stands represent a subset of those studied by Ohmann et al. (1989). Mean annual temperature, mean annual precipitation, and actual evapotranspiration were calculated from measurements obtained at the nearest weather station (Grigal and Ohmann, 1992); the mean distance from a weather station to a stand was $23 \mathrm{~km}$. We used data for the period 1964 through 1985 to characterize the climate of each stand and to calculate a hydrologic balance (see Grigal and Ohmann, 1992). Mean annual temperature ranged from $3.7^{\circ} \mathrm{C}$ in northwestern Minnesota to $5.8^{\circ} \mathrm{C}$ in Michigan; mean annual precipitation varied from 647 to $844 \mathrm{~mm}$ (Grigal and Ohmann, 1992). Actual evapotranspiration increased from 513 $\mathrm{mm}$ in northern Minnesota to $548 \mathrm{~mm}$ in Michigan. Nitrogen deposition was $0.9 \mathrm{~g} \mathrm{~N} \mathrm{~m}^{-2} \mathrm{yr}^{-1}$ in northwestern Minnesota and increased to $1.2 \mathrm{~g} \mathrm{~N} \mathrm{~m}^{-2} \mathrm{yr}^{-1}$ in southeastern Lower Michigan. Overstory properties and soil texture have been summarized in Table 1. Further detail regarding bedrock geology, glacial geology, and soil taxonomy can be found in Ohmann et al. (1989).

Forest floor and mineral soil samples were collected from June through September 1985. Within each stand, five trees were randomly selected as points to initiate forest floor and soil sampling (Ohmann et al., 1989). Three forest floor samples (including $\mathrm{Oi}, \mathrm{Oe}$, and $\mathrm{Oa}$ horizons) were collected at a distance of $1.5 \mathrm{~m}$ and at azimuths of 45,115 , and $225^{\circ}$ from each tree. Forest floor samples were collected within a circular $113-\mathrm{cm}^{2}$ sampling frame, and were thoroughly mixed within a polyethylene bag; coarse organic matter (i.e., small branches) was excluded from the sample. Following the removal of forest floor material, a bucket auger was used to collect the upper $25 \mathrm{~cm}$ of the mineral soil. Soil samples were thoroughly mixed within a polyethylene bag, and coarse fragments $>20 \mathrm{~mm}$ were discarded. Mineral soil samples were sieved when moist (3 $\mathrm{mm}$ ), and coarse fragments and roots were removed. A more detailed description of forest floor and mineral soil sampling can be found in Grigal and Ohmann (1992). The 15 forest floor and 15 mineral soil samples collected in each stand were composited and stored at $0^{\circ} \mathrm{C}$ prior to analysis.
Table 1. Overstory and edaphic properties of five forest types in the Upper Great Lakes region. The number of stands sampled is within the parentheses following each forest type.

\begin{tabular}{lcccc}
\hline Forest type & $\begin{array}{c}\text { Stand } \\
\text { age }\end{array}$ & $\begin{array}{c}\text { Overstory } \\
\text { biomass }\end{array}$ & $\begin{array}{c}\text { Mean } \\
\text { annual } \\
\text { increment }\end{array}$ & $\begin{array}{c}\text { Soil } \\
\text { (silt + clay) }\end{array}$ \\
\hline & $y r$ & t ha $^{-1}$ & t ha $^{-1}$ yr $^{-1}$ & $\%$ \\
Jack pine (38) & $52(8.4) \dagger$ & $79(24.4)$ & $1.5(0.5)$ & $12.2(7.9)$ \\
Red pine (22) & $35(7.8)$ & $88(22.2)$ & $2.6(0.7)$ & $18.0(14.8)$ \\
Balsam fir (22) & $61(6.0)$ & $97(19.3)$ & $1.6(0.4)$ & $46.0(18.2)$ \\
Sugar maple (36) & $66(6.0)$ & $144(26.6)$ & $2.2(0.4)$ & $42.6(18.4)$ \\
Quaking aspen (36) & $49(5.8)$ & $106(26.8)$ & $2.1(0.5)$ & $44.0(20.3)$ \\
\hline
\end{tabular}

$\dagger$ Values are means with standard deviations in parentheses.

\section{Microbial Respiration and Nitrogen Mineralization}

We used a modified-microlysimeter technique to simultaneously determine the kinetics of microbial respiration and $\mathrm{N}$ mineralization (Nadelhoffer, 1990). Two replicate 30-g subsamples of forest floor or mineral soil were incubated in Falcon filtration units (Model 7102, Becton Dickinson Labware, Lincoln Park, NJ) that were modified by sealing each port with a rubber septum and replacing the original nitrocellulose filter with a glass-fiber filter (Whatman GF-A). The microlysimeters were made air tight by sealing the lid and seams with silicone rubber. After the silicone rubber had cured, $5 \mathrm{~mL}$ of air were injected, and pressure was measured using a transducer (Parkin et al., 1984) to ensure that each had an air-tight seal. The septa were removed, and each subsample was extracted with 100 $\mathrm{mL}$ of $0.01 \mathrm{M} \mathrm{CaCl}_{2}$ to determine initial $\mathrm{NH}_{4}^{+}-\mathrm{N}$ and $\mathrm{NO}_{3}^{-}-$ $\mathrm{N}$ concentrations. Following the extraction, $25 \mathrm{~mL}$ of minus$\mathrm{N}$ nutrient solution (Stanford and Smith, 1972) were added to each microlysimeter, and the samples were brought to field capacity ( $-0.03 \mathrm{MPa})$ using a hand-operated vacuum pump; the excess minus- $N$ nutrient solution was discarded. The airtight seal of each microlysimeter was again tested by injecting $5 \mathrm{~mL}$ of air and monitoring pressure within the microlysimeter using a pressure transducer (Parkin et al., 1984). The microlysimeters were flushed with five headspace volumes of $\mathrm{CO}_{2}$ free air and were kept air tight for the incubation period.

The microlysimeters were incubated in the dark at $35^{\circ} \mathrm{C}$ for 32 wk. Samples $(0.4 \mathrm{~mL})$ of headspace gas from each microlysimeter were withdrawn at Weeks 1 and 2 , and at 2-wk intervals thereafter. Gas samples were analyzed for $\mathrm{CO}_{2}$ using a Tracor 540 gas chromatograph (Tracor Instruments, Austin, TX) equipped with Porapak Q (Millipore Corp., Milford, MA) and molecular sieve columns in series with a thermal conductivity detector. The columns were maintained at $55^{\circ} \mathrm{C}$ during analysis, and $\mathrm{He}\left(25 \mathrm{~mL} \mathrm{~min}^{-1}\right)$ was used as a carrier gas. Inorganic $N$ was determined at $1,2,4,8,16$, and 32 wk by extracting the contents of each microlysimeter as described above. Ammonium-N and $\mathrm{NO}_{3}^{-}-\mathrm{N}$ were determined colorimetrically using an Alpkem RFA 300 (Alpkem Corp., Wilsonville, OR). Following extraction, each microlysimeter was flushed with five headspace volumes of $\mathrm{CO}_{2}$-free air to replenish any $\mathrm{O}_{2}$ that had been consumed during microbial respiration.

\section{Statistical Analysis}

Product accumulation curves for microbial respiration and $\mathrm{N}$ mineralization were plotted for each microlysimeter, and data were fit to a first-order rate equation using nonlinear regression. In all cases, visual inspection indicated that the data fit a first-order model. Regression coefficients for the model $\left[y=a\left(1-\mathrm{e}^{-k t}\right)\right.$, where $t$ is time in weeks] provided estimates of the $\mathrm{C}$ or $\mathrm{N}$ pool $(a)$ that can be respired or mineralized, respectively, and the rate constant $(k)$ for each process. We assumed respired $C$ and mineralized $N$ ( $a$ from the equation) represented labile $\mathrm{C}$ and $\mathrm{N}$ pools within the soil, and we 
use both sets of terms synonymously. These quantities (i.e., micrograms $\mathrm{C}$ or $\mathrm{N}$ per gram) were expressed on an areal basis (grams $\mathrm{C}$ or $\mathrm{N}$ per square meter) using the mass of forest floor contained within the $113-\mathrm{cm}^{2}$ sampling frame or the mineral soil bulk densities (David et al., 1988). These data had been corrected for coarse fragment content. Pools and rate constants for the two replicate subsamples of forest floor and mineral soil material from each stand were averaged, and all subsequent statistical analyses were conducted using stand means.

To compensate for differences in temperature when comparing our rate constants with those in the literature, we used the following equation: $k_{2}=\left\{\log Q_{10}+\left[10 / T_{2}+35\right)\right] \log$ $\left.\left.k_{1}\right\} /\left[10 / T_{2}-35\right)\right]$, where, $k_{2}$ is the rate constant determined at temperature $T_{2}, k_{1}$ is the rate constant at $35^{\circ} \mathrm{C}$, and $Q_{10}=$ $\left(k_{1} / k_{2}\right)^{10 /\left(T_{1}-T_{2}\right)}$; where $T_{1}$ is the temperature at which the rate constant $k_{1}$ was determined, and $T_{2}$ is the temperature for which an adjusted rate constant, $k_{2}$, is desired. $\mathrm{A} Q_{10}$ of 2 was used for microbial respiration and $\mathrm{N}$ mineralization (Stanford et al., 1973).

The influence of forest type on organic matter pools and rate constants for microbial respiration and $\mathrm{N}$ mineralization was determined with a one-way analysis of variance for an unbalanced design (SAS Institute, 1988). Forest floor and mineral soil were analyzed separately, with forest type considered a fixed effect in the ANOVA models. Differences among least square means were tested using a Bayes least significant difference (Smith, 1978). In addition, linear regression analyses were used to explore the relationships between kinetic parameters and MAP, MAT, AET, soil texture, organic C, and total N. Significance for all statistical analyses was accepted at $\alpha$ $=0.05$.

\section{RESULTS}

\section{Forest Floor}

Forest floor organic $\mathrm{C}$ ranged from $1580 \mathrm{~g} \mathrm{C} \mathrm{m}^{-2}$ in the red pine forest to $2525 \mathrm{~g} \mathrm{C} \mathrm{m}^{-2}$ in the balsam fir forest, and was significantly greater in the balsam fir forest than in the other forest types (Table 2). Microbial respiration and $\mathrm{N}$ mineralization conformed well to firstorder kinetics. The nonlinear regression analyses were all highly significant, with coefficients of determination ranging from 0.97 to 1.00 . Respired $C$ was not significantly different among the forest types even though it varied from $67.0 \mathrm{~g} \mathrm{C} \mathrm{m}^{-2}$ in the forest floor of jack pine to $91.9 \mathrm{~g} \mathrm{C} \mathrm{m}^{-2}$ in that of the sugar maple forest (Table 2). Respired $\mathrm{C}$ averaged $4 \%$ of forest floor organic $\mathrm{C}$ in all forest types. Among stands, respired $\mathrm{C}$ was significantly but poorly correlated with MAP $(r=-0.207)$, organic $\mathrm{C}(r=0.673)$, and total $\mathrm{N}(r=0.648)$. These variables, however, were not significantly correlated with respired $\mathrm{C}$ within a forest type.

Rate constants for microbial respiration were significantly different among forest types, even though the means fell within a relatively narrow range of values (Table 2). Mean rate constants for forest floors of quaking aspen and sugar maple $\left(0.269 \mathrm{wk}^{-1}\right)$ were significantly lower than those in the coniferous forests. Turnover times for respired $\mathrm{C}$ pools, calculated from the rate constants $(1 / k)$, were relatively rapid and ranged from 3.3 to 3.7 wk among forest types. Rate constants for microbial respiration were not significantly correlated with climatic variables or with soil $\mathrm{C}$ and $\mathrm{N}$ pools.

Total $\mathrm{N}$ in the forest floor ranged from $37 \mathrm{~g} \mathrm{~N} \mathrm{~m}^{-2}$ (red pine) to $77 \mathrm{~g} \mathrm{~N} \mathrm{~m}^{-2}$ (balsam fir) among the forest types; differences were significant (Table 2). In general, the pine-dominated forests had the lowest forest floor total $\mathrm{N}$, whereas the hardwood forests had intermediate values. Mineralized $\mathrm{N}$ in the sugar maple forest floor $\left(4.1 \mathrm{~g} \mathrm{~N} \mathrm{~m}^{-2}\right)$ was significantly greater than in the other forest types (Table 2). Mineralized $N$ was $4 \%$ of total $N$ in the balsam fir and quaking aspen forest floors and $6 \%$ of total $\mathrm{N}$ in the other forests. Organic $\mathrm{C}(r=0.673)$ and total $\mathrm{N}(r=0.648)$ in forest floor were significantly correlated with mineralized $\mathrm{N}$ pools among stands. Climatic variables were not significantly correlated with mineralized $\mathrm{N}$ within a forest type or among all 154 stands. Mineralized $\mathrm{N}$ was well correlated with respired $\mathrm{C}$ among stands $\left(\mathrm{g} \mathrm{C}_{\text {resp }} \mathrm{m}^{-2}=15.9 \mathrm{~g} \mathrm{~N}_{\min } \mathrm{m}^{-2}+\right.$ 27.4; $\mathrm{MSE}=653.9 ; r=0.853 ; n=154 ; P \stackrel{\min }{=} 0.0001$ ).

Rate constants for $\mathrm{N}$ mirieralization were significantly lower in the jack pine and balsam fir $\left(0.326 \mathrm{wk}^{-1}\right)$ forest floor compared with those of other forest types. The most rapid rate constant was in the quaking aspen forest floor, where the mean was 0.556 wk $^{-1}$. Calculated turnover times for mineralized $\mathrm{N}$ (at $35^{\circ} \mathrm{C}$ ) ranged from 1.8 to 3.9 wk. Although MAP $(r=-0.210)$ was significantly correlated with rate constants for $\mathrm{N}$ mineralization, it accounted for a very small proportion of the variation among the 154 stands. Climatic variables were not correlated with rate constants within a forest type.

\section{Mineral Soil}

Organic $\mathrm{C}$ was significantly lower in the surface mineral soil of the pine-dominated forests compared with the fir and hardwood forests, with the lowest organic $\mathrm{C}$ in the jack pine forest $\left(3335 \mathrm{~g} \mathrm{C} \mathrm{m}^{-2}\right.$ ) and highest in the balsam fir forest ( $5485 \mathrm{~g} \mathrm{C} \mathrm{m}^{-2}$; Table 2). Mean respired $\mathrm{C}$ was four to six times greater in the mineral soil than in the forest floor. Although means ranged from $288 \mathrm{~g}$ $\mathrm{C} \mathrm{m}^{-2}$ in the balsam fir forest to $356 \mathrm{~g} \mathrm{C} \mathrm{m}^{-2}$ in the red pine forest, differences among forest types were not significant (Table 2). Respired C represented 5\% of soil organic $\mathrm{C}$ in the balsam fir forest and $\approx 10 \%$ in the pine forests; the quaking aspen and sugar maple forests had intermediate values (both 7\%). The MAP $(r=0.197)$, organic $C(r=0.440)$, and total $N(r=0.473)$ were significantly correlated with respired $\mathrm{C}$ pools among the 154 stands. Climatic variables were not significantly correlated with respired $\mathrm{C}$ pools within a forest type.

Rate constants for respired C differed significantly among forest types but ranged narrowly from 0.303 to $0.350 \mathrm{wk}^{-1}$ (Table 2). Rate constants were not significantly different in the hardwood forests, nor were they significantly different among the pine forests. Calculated turnover times for respired $\mathrm{C}$ were $\approx 3 \mathrm{wk}$. Rate constants were significantly but poorly correlated with MAT $(r=0.229)$, MAP $(r=0.165)$, and organic C $(r=$ $-0.226)$ among all 154 stands. Within a forest type, these relationships were not significant.

Total $\mathrm{N}$ in mineral soil was not significantly different between the pine-dominated forests. However, total $\mathrm{N}$ in soil was significantly lower in those forests compared with the others (Table 2). The largest mineralized $\mathrm{N}$ pool was in the quaking aspen forest $\left(29.3 \mathrm{~g} \mathrm{~N} \mathrm{~m}^{-2}\right)$, not significantly different from those in the sugar maple and red pine forests. The lowest mineralized $\mathrm{N}$ pool was in the balsam fir forest $\left(15.3 \mathrm{~g} \mathrm{~N} \mathrm{~m}^{-2}\right)$, where only $5.4 \%$ of total $\mathrm{N}$ was mineralized during the 32-wk incubation. Mineralized $\mathrm{N}$ was $\approx 8.5 \%$ of total $\mathrm{N}$ in the hardwood 
Table 2. Organic matter pools and rate constants for microbial respiration and $\mathbf{N}$ mineralization for five forest types in the Upper Great Lakes region. Means are least square estimates based on a one-way ANOVA testing the significance of differences among forest types.

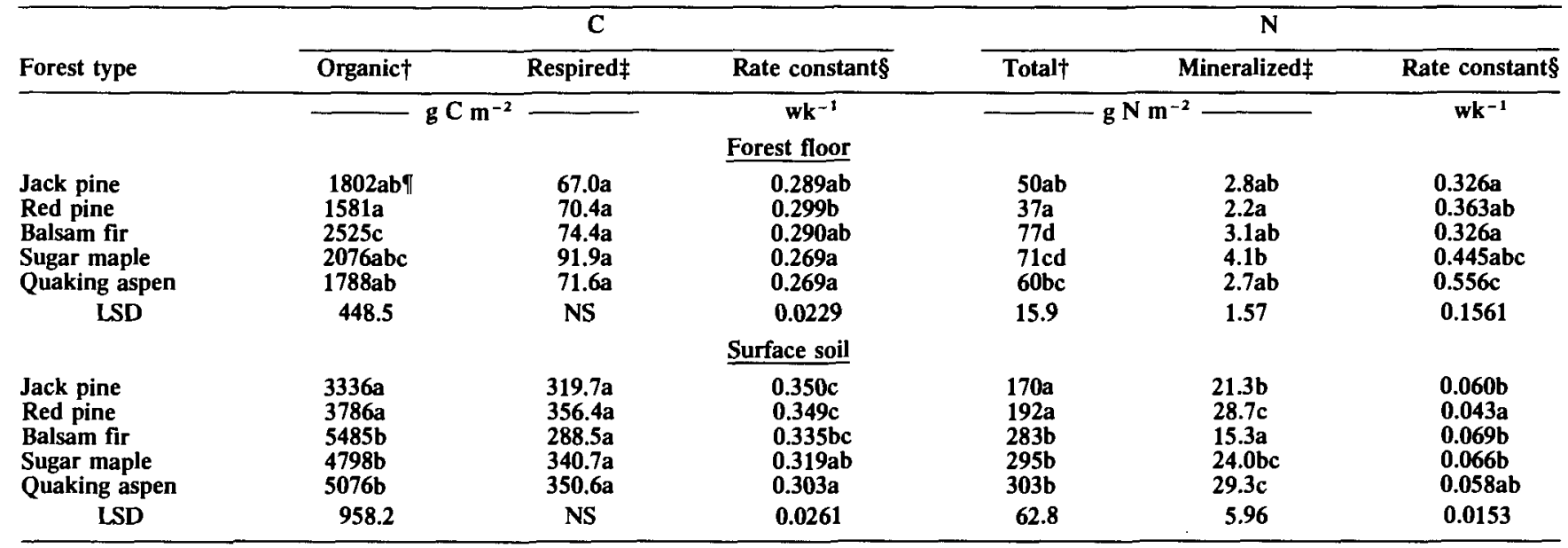

† Summarized from David et al. (1988).

$¥$ a from first-order equation.

$\$ k$ from first-order equation.

ๆ Means within a column that have the same letter are not significantly different. Means are least square estimates based on a one-way ANOVA testing the significance of differences among forest types; NS = not significant.

forests, and was an even larger proportion in the jack pine $(12 \%)$ and red pine $(15 \%)$ forests. Mineralized N was weakly correlated with AET $(r=0.274)$ and total $\mathrm{N}(r=0.479)$ among the 154 stands. However, mineralized $\mathrm{N}$ correlated well with respired $\mathrm{C}$ pools $\left(\mathrm{g} \mathrm{C}_{\mathrm{resp}}\right.$ $\mathrm{m}^{-2}=159.9+7.1 \mathrm{~g} \mathrm{~N}_{\min } \mathrm{m}^{-2} ; \mathrm{MSE}=12870.5 ; r$ $=0.616 ; n=154 ; P=0.0001)$. We found no significant relationships between climatic parameters and mineralized $\mathrm{N}$ pools for individual forest types.

Rate constants for $\mathbf{N}$ mineralization in soil were an order of magnitude lower than those in the forest floor (Table 2). The highest rate constant, that in the balsam fir forest $\left(0.069 \mathrm{wk}^{-1}\right)$, was not significantly different than those measured in the hardwood and jack pine forests (Table 2). Rate constants in the red pine (0.043 $\left.w^{-1}\right)$ and quaking aspen $\left(0.058 \mathrm{wk}^{-1}\right)$ forests were not significantly different. Turnover times calculated from rate constants $\left(\right.$ at $35^{\circ} \mathrm{C}$ ) ranged from 14 to $23 \mathrm{wk}$. Neither the climatic parameters nor $\mathrm{C}$ and $\mathrm{N}$ pools were significantly correlated with the rate constants within a forest type or among all 154 stands.

\section{DISCUSSION}

\section{Annual In Situ Fluxes and Laboratory-Defined Pools}

Distinguishing rates of microbial respiration from total soil respiration has been difficult (Minderman and Vulto, 1973; Schlesinger, 1977), but remains important in understanding $\mathrm{C}$ dynamics within forested ecosystems. Due to the difficulty in separating these fluxes, few data exist regarding annual rates of microbial respiration from forested soils. However, Weber $(1985 ; 1990 a, b)$ has measured total soil respiration in forests similar to those we studied. Annual $\mathrm{CO}_{2}$ emissions calculated from his data suggest that this flux is equivalent among jack pine (270 $\left.\mathrm{g} \mathrm{C} \mathrm{m}^{-2} \mathrm{yr}^{-1}\right)$, red pine $\left(220 \mathrm{~g} \mathrm{C} \mathrm{m}^{-2} \mathrm{yr}^{-1}\right)$, and quaking aspen $\left(250 \mathrm{~g} \mathrm{C} \mathrm{m}^{-2} \mathrm{yr}^{-1}\right)$ forests. However, Schlentner and Van Cleve (1985) reported a somewhat higher flux
( $386 \mathrm{~g} \mathrm{C} \mathrm{m}^{-2} \mathrm{yr}^{-1}$ ) for an Alaskan quaking aspen forest. Assuming that soil microbes contribute $50 \%$ of the total respiratory flux (Ewel et al., 1987; Schlesinger, 1977), microbial respiration would equal 110 and $135 \mathrm{~g} \mathrm{C} \mathrm{m}^{-2}$ $\mathrm{yr}^{-1}$ in the red pine and jack pine forests, respectively, and estimates range from 125 to $190 \mathrm{~g} \mathrm{C} \mathrm{m}^{-2} \mathrm{yr}^{-1}$ in the quaking aspen forest. These estimates represent $\approx 30 \%$ of the labile $C$ (i.e., respired C) stored within the forest floor and mineral soil of these forest types.

Estimates of soil respiration for balsam fir or sugar maple forests in the Lake States region are not available. However, Goreau (1981) measured a flux of $670 \mathrm{~g} \mathrm{C}$ $\mathrm{m}^{-2} \mathrm{yr}^{-1}$ for a northern hardwood forest in the northeastern USA. Microbial respiration estimated from this flux ( $335 \mathrm{~g} \mathrm{C} \mathrm{m}^{-2} \mathrm{yr}^{-1}$ at $50 \%$ of soil respiration) represented $77 \%$ of the respired $C$ pool we measured in the sugar maple forest type. Because $C$ stored within the forest floor and surface mineral soil of this northeastern forest was greater than that in similar Great Lakes forests (Federer, 1983; Grigal and Ohmann, 1992), and because of differences in climate and aboveground litter production (Gosz et al., 1972; Zak et al., 1986), annual rates of microbial respiration in the Northeast are probably greater than in Great Lakes forests.

Carbon inputs from aboveground litter are relatively well documented for jack pine (mean $=94 \mathrm{~g} \mathrm{C} \mathrm{m}^{-2}$; Foster and Morrison, 1976; MacLean and Wein, 1978a,b; Weber, 1987), red pine (mean $=197 \mathrm{~g} \mathrm{C} \mathrm{m}^{-2}$; Alban, 1982; Perala and Alban, 1982; Tappeiner and Alm, 1975; Weber, 1990b), sugar maple (mean $=204 \mathrm{~g} \mathrm{C} \mathrm{m}^{-2}$; McClaugherty et al., 1985; Pregitzer and Burton, 1991; Zak et al., 1986), and quaking aspen (mean $=160 \mathrm{~g} \mathrm{C}$ $\mathrm{m}^{-2}$; Alban, 1982; McClaugherty et al., 1985) forests in the upper Great Lakes region. Estimates were not available for balsam fir forests; however, Sprugel (1984) measured inputs of $170 \mathrm{~g} \mathrm{C} \mathrm{m}^{-2} \mathrm{yr}^{-1}$ in the southeastern USA. These inputs are comparable to in situ estimates of microbial respiration. However, the turnover of annual aboveground litter production typically occurs over 
several years, suggesting that only a fraction of this material is metabolized on an annual basis (Weber, 1990b). Root litter and exudates, in addition to aboveground inputs, would undoubtedly increase total $C$ inputs well beyond estimates of microbial respiration.

Our measures of labile $\mathrm{C}$ within the forest floor and mineral soil were far greater than that annually supplied through aboveground litter. For example, $\mathrm{C}$ from aboveground litter represents 30 (jack pine) to $47 \%$ (balsam fir) of the labile $\mathrm{C}$ already stored within the forest floor and mineral soil, and not all $\mathrm{C}$ additions from litter are labile. More importantly, respired $\mathrm{C}$ pools (i.e., forest floor + mineral soil) in the jack pine, red pine, and quaking aspen forest types were three to four times greater than annual in situ estimates of microbial respiration. Respired $\mathrm{C}$ in the sugar maple forest was also greater than in situ estimates of microbial respiration, although these data are weaker. Nevertheless, our data suggest that labile $\mathrm{C}$ in the forest floor and mineral soil was far greater than the amounts of $C$ added through annual aboveground litterfall and that respired by soil microbes.

Pastor et al. (1984) demonstrated that in situ $\mathrm{N}$ mineralization was well correlated with $\mathbf{N}$ in aboveground litter. In our study, mineralized $\mathrm{N}$ in forest floor was approximately equal to that contained in the annual litterfall of jack pine (mean $=4.2 \mathrm{~g} \mathrm{~N} \mathrm{~m}^{-2} \mathrm{yr}^{-1}$; Perala and Alban, 1982; Weber, 1987), red pine (mean $=3.5$ $\mathrm{g} \mathrm{N} \mathrm{m}^{-2} \mathrm{yr}^{-1}$; Perala and Alban, 1982; Weber, 1990b), sugar maple (mean $=2.5 \mathrm{~g} \mathrm{~N} \mathrm{~m}^{-2} \mathrm{yr}^{-1}$; Pregitzer and Burton, 1991; Pastor et al., 1984; Zak et al., 1986), and quaking aspen forests (mean $=4.0 \mathrm{~g} \mathrm{~N} \mathrm{~m}^{-2} \mathrm{yr}^{-1}$; Perala and Alban, 1982). If mineralized $\mathrm{N}$ pools in the forest floor and mineral soil are combined, however, they far exceed estimates of litterfall $\mathrm{N}$ and of in situ mineralization rates. For example, mean mineralized $\mathbf{N}$ across all forest types $\left(53.6 \mathrm{~g} \mathrm{~N} \mathrm{~m}^{-2}\right.$, forest floor + mineral soil) was five times greater than any annual rate reported using in situ soil incubations (Nadelhoffer et al., 1983; McClaugherty et al., 1985; Mladenoff, 1987; Pastor et al., 1984; Plymale et al., 1987; Zak and Pregitzer, 1990; Zak et al., 1991). The in situ release of $\mathrm{N}$ must be limited by factors other than substrate pool size. Our results suggest that there are relatively large quantities of $\mathrm{N}$ that could become available if soil temperature and moisture were more suitable for microbial activity.

\section{Rate Constants for Microbial Respiration and Nitrogen Mineralization}

Relatively few studies have quantified rate constants for microbial respiration in forested ecosystems. In the northeastern USA Harris and Rhia (1991) found mean values $\left(23^{\circ} \mathrm{C}\right)$ of $0.145 \mathrm{wk}^{-1}$ and $0.102 \mathrm{wk}^{-1}$ in sugar maple and red pine forest floor, respectively. When adjusted to an incubation temperature of $23^{\circ} \mathrm{C}$ ( $k_{\text {sugar maple }}$ $=0.117 \mathrm{wk}^{-1}, k_{\text {red pine }}=0.130 \mathrm{wk}^{-1}$ ) our values closely agree with theirs. Additionally, the overall mean for forest floor $\left(0.286 \mathrm{wk}^{-1}\right)$ and mineral soil $\left(0.331 \mathrm{wk}^{-1}\right)$ are similar to the values used by Parton et al. (1987) to describe the decomposition of metabolic surface litter $\left(0.28 \mathrm{wk}^{-1}\right)$ and metabolic soil litter $\left(0.35 \mathrm{wk}^{-1}\right)$.

The relatively narrow range of rate constants for microbial respiration among forests suggests that a func- tionally similar class of organic compound(s) was metabolized during the laboratory incubation. At $35^{\circ} \mathrm{C}$, turnover $(1 / k)$ of this material in both forest floor and mineral soil occurred over an approximate 3-wk period. During the growing season, however, surface soil temperatures in the upper Great Lakes region are much lower and average $11{ }^{\circ} \mathrm{C}(\mathrm{N}$. MacDonald, 1992, personal communication). At this temperature, the turnover time for respired $\mathrm{C}$ is 16 to $18 \mathrm{wk}$, a period of time equivalent to the annual growing season. It is important to point out, however, that soil water deficits during mid-summer undoubtedly constrain these rates; the aforementioned values were determined at field capacity. Due to the rapid and narrow range of rate constants, in situ rates of microbial respiration are likely to be primarily driven by environmental factors and secondarily by $\mathrm{C}$ availability.

Rate constants for $\mathrm{N}$ mineralization were far more variable than those for microbial respiration, and differed by an order of magnitude between forest floor and mineral soil material. Differences in litter chemistry are partially reflected in the variation we found among forest floor means. For example, the lowest rate constants occurred in the coniferous forests, where inputs of lignified litter generally slow decomposition and $\mathrm{N}$ mineralization (Perala and Alban, 1982; Pastor et al., 1984; McClaugherty et al., 1985). Nevertheless, all the forest floor rate constants produced rapid turnover times (e.g., 1-3 wk at $35^{\circ} \mathrm{C}$ ), which represent relatively short periods of time compared with more stable forms of organic matter. Adjusting our rate constants to mean field temperature increased labile $\mathrm{N}$ turnover to $\approx 13 \mathrm{wk}$. In contrast, turnover in mineral soil averaged $17 \mathrm{wk}$ at laboratory temperature, and $90 \mathrm{wk}$ at field temperature. Although the extent to which forest floor or mineral soil function as the major source of $\mathrm{N}$ can vary (Federer, 1983; Binkley and Hart, 1989), the potential for a rapid turnover of $N$ in the forest floors we studied confirms that it is a significant source of $\mathbf{N}$ for tree growth.

The differences we observed in rate constants for forest floor and mineral soil suggest that $\mathrm{N}$ may have been mineralized from different types of organic matter in these ecosystem compartments. Furthermore, the relatively low rate constants for mineral soil suggest that $\mathbf{N}$ was liberated from organic matter that was relatively more recalcitrant than that in the forest floor. Our values for mineral soil were lower than those measured by Burger and Prichett (1984) in a mixed pine (slash pine, Pinus elliotii Engelm., and longleaf pine, Pinus palustris Miller) forest of the southeast USA $\left(0.14 \mathrm{wk}^{-1}\right.$, corrected to 35 $\left.{ }^{\circ} \mathrm{C}\right)$. The most rapid rate constant we measured was approximately one-half that value $\left(0.060 \mathrm{wk}^{-1}\right)$. Although we have one data point from a forested ecosystem for comparison, our rate constants fall within the range of values reported for agricultural soils $\left(0.028-0.266 \mathrm{wk}^{-1}\right.$ at $35^{\circ} \mathrm{C}$; Stanford and Smith, 1972; Juma et al., 1984). Juma et al. (1984) speculated that the range of rate constants reported for agricultural soils suggests that an array of labile organic compounds serve as substrates for mineralization. The differences we found between the mineral soil and forest floor support this contention.

Several investigators have demonstrated a linear relationship between net $\mathrm{C}$ and $\mathrm{N}$ mineralization from organic substrates with low $\mathrm{C} / \mathrm{N}$ ratios (Gilmore et al., 
1985; Gale and Gilmore, 1986; Moorhead et al., 1987). During the first $14 \mathrm{~d}$ of their study, Gale and Gilmore (1988) observed that $\mathrm{C}$ and $\mathrm{N}$ were mineralized at a ratio of $6: 1$; thereafter, the ratio narrowed to $\approx 1: 1$ until Day 30 . In our study, $\mathrm{C}$ and $\mathrm{N}$ were liberated at a ratio of $7: 1$ (i.e., regression slope) in mineral soil, which closely matches the initial relationship found in the aforementioned study. This ratio was much wider (16:1) in forest floor material, even though rate constants for $\mathrm{N}$ mineralization were ten times greater than those in the mineral soil. Nitrogen release from forest floor material occurred at a faster rate, but the total pool size was much smaller than that in the mineral soil. This relationship illustrates the interplay between kinetic rate constants and pool sizes in regulating $\mathrm{C}$ and $\mathrm{N}$ dynamics within the soil. Models considering the temporal dynamics of substrate pools as well as rate constants may provide more precise predictions of these processes.

Neither labile $\mathrm{C}$ and $\mathrm{N}$ pools nor rate constants for microbial respiration and $\mathrm{N}$ mineralization were well correlated with regional climatic parameters. Although one could therefore conclude that labile organic matter within a forest type does not vary along a regional climatic gradient, our data may not reflect the site-specific climatic conditions that influence the cycling of $\mathrm{C}$ and N. Factors that modify regional climate, such as physiographic differences and proximity to lakes, were not considered by our weather station data. Some of the variation that we observed in pools of respired $\mathrm{C}$ and mineralized $\mathrm{N}$ may therefore be due to differences in local climate; such differences clearly play a strong role in structuring the spatial distribution of forest ecosystems. Site-specific climatic data are necessary to fully clarify the link between climate and labile organic matter dynamics.

The comparisons that we have made are based on data obtained from laboratory incubations where conditions differ greatly from those in the field. It could be argued that our approach does not accurately estimate labile pools of $\mathrm{C}$ and $\mathrm{N}$. For example, our samples were stored at $0{ }^{\circ} \mathrm{C}$, and numerous studies have demonstrated that freezethaw cycles temporarily increase rates of microbial activity and, in particular, rates of denitrification (Christensen and Tiedje, 1990; Goodroad and Keeney, 1984; Groffman and Tiedje, 1989). This phenomenon has been attributed to increases in $\mathrm{C}$ availability resulting from the death of microbial cells and from the release of physically protected organic matter (Soulides and Allison, 1961; Mack, 1963). Although such increases could elevate initial respiration or mineralization rates, it seems unlikely that they would cause large overestimates of respired $C$ or mineralized $\mathrm{N}$ pools during a 32-wk incubation. Nevertheless, such an alternative should not be ignored and could be evaluated by incubating fresh intact soil cores rather than homogenized stored samples.

In addition, our incubations were conducted at a temperature $\left(35^{\circ} \mathrm{C}\right)$ not commonly experienced by soil microbes in northern temperate forests. Given the difference between field and laboratory temperatures, our incubations may have favored organisms whose temperature and moisture optima were higher than those active under field conditions. We cannot quantitatively determine how such changes may have influenced microbial respiration and $\mathrm{N}$ mineralization. Conducting laboratory incubations at temperatures nearer field conditions, or studies including a range of incubation temperatures, however, could provide insight into these influences.

\section{CONCLUSIONS}

Our results indicate that, although there are differences in respired $\mathrm{C}$ and mineralized $\mathrm{N}$ in forest floor and surface mineral soil, rate constants and pools do not vary predictably with regional climate. Although environment and substrate both influence microbial activity, the conclusion that we draw from our analysis is that the dominant variable controlling the in situ release of $\mathrm{C}$ and $\mathrm{N}$ from labile organic matter is the local environment. This is supported by the narrow range of rate constants, indicating that labile organic matter pools were functionally similar among forest types. Additional support for our conclusion stems from the greater quantities of $\mathrm{C}$ and $\mathrm{N}$ metabolized under laboratory conditions of temperature and water availability compared with those released in situ. Therefore, factors other than substrate chemistry and pool size must limit the release of $\mathrm{C}$ and $\mathrm{N}$ from labile organic matter under field conditions. We suggest that these processes may be more strongly influenced by local temperature and moisture regimes than by differences in litter chemistry related to overstory composition. If we are correct, then attempts to model the dynamics of labile $\mathrm{C}$ and $\mathrm{N}$ in forested ecosystems should emphasize local environmental parameters more than litter chemistry. Moreover, our results have clear implications for a potential positive feedback mechanism of global warming on $\mathrm{C}$ and $\mathrm{N}$ dynamics.

\section{ACKNOWLEDGMENTS}

This research was funded by the U.S. Forest Service North Central Forest Experiment Station under the National Vegetation Survey Research Program of the National Acid Precipitation Assessment Program. Funds provided by the McIntireStennis Forestry Research Act (PL 87-788) and by Project 25 054 of the University of Minnesota Agricultural Experiment Station (Journal Series no. 19980) are also gratefully acknowledged. We thank Brenda Memering, Carole Bell, Amy Merrill, and Bill Holmes for their assistance in the laboratory.

\section{REFERENCES}

Alban, D.H. 1982. Effect of nutrient accumulation by aspen, spruce, and pine on soil properties. Can. J. Bot. 60:2263-2269.

Billings, W.D., K.M. Petterson, G.R. Shaver, and A.W. Trent. 1977. Root growth, respiration, and carbon dioxide evolution in an arctic tundra soil. Arct. Alp. Res. 9:129-137.

Binkley, D., and S.C. Hart. 1989. The components of nitrogen availability assessments in forest soils. Adv. Soil Sci. 10:57112.

Birdsey, R.A. 1990. Inventory of carbon storage and accumulation in U.S. forest ecosystems. p. 24-31. In H.E. Burkhart et al. (ed.) Research in forest inventory, monitoring, growth, and yield. Proc. IUFRO World Congr., Montreal. 5-11 Aug. 1990. School of For. and Wildl. Resour. Publ. FWS-3090. Virg. Polytech. Inst. and State Univ., Blacksburg.

Burger, J.A., and W.L. Prichett. 1984. Effects of clearfelling and site preparation on nitrogen mineralization in a southern pine stand. Soil Sci. Soc. Am. J. 48:1432-1437.

Christensen,S., and J.M. Tiedje. 1990. Brief and vigorous $\mathrm{N}_{2} \mathrm{O}$ production by soil at spring thaw. J. Soil Sci. 41:1-4.

Cole, D., and M. Rapp. 1981. Elemental cycling in forested ecosystems. p. 341-411. In D.E. Reichle (ed.) Dynamic properties of forest ecosystems. Cambridge Univ. Press, New York.

David, M.D., D.F. Grigal, L.F. Ohmann, and G.Z. Gertner. 1988. S, C, and N relationships in forest soils across the northern Great Lakes States as affected by atmospheric deposition and vegetation. Can. J. For. Res. 18:1386-1391. 
Ewel, K.C., W.P. Cropper, and H.L. Gholtz. 1987. Soil $\mathrm{CO}_{2}$ evolution in Florida slash pine plantations: II. Importance of root respiration. Can. J. For. Res. 17:330-333.

Federer, C.A. 1983. Nitrogen mineralization and nitrification: depth variation in four New England forest soils. Soil Sci. Soc. Am. J. 47:1008-1014.

Foster, N.W., and I.K. Morrison. 1976. Distribution and cycling of nutrients in a natural Pinus banksiana ecosystem. Ecology $57: 110-120$.

GaIe, P.M., and J.T. Gilmore. 1986. Carbon and nitrogen mineralization kinetics for poultry litter. J. Environ. Qual. 15:423426.

Gale, P.M., and J.T. Gilmore. 1988. Net mineralization of carbon and nitrogen under aerobic and anaerobic conditions. Soil Sci. Soc. Am. J. 52:1006-1010.

Gilmore, J.T., M.D. Clark, and G.C. Sigua. 1985. Estimating net nitrogen mineralization from carbon dioxide evolution. Soil Sci. Soc. Am. J. 49:1398-1402.

Goodroad, L.L., and D.R. Keeney. 1984. Nitrous oxide emission from forest, marsh, and prairie ecosystems. J. Environ. Qual. 13:448-452.

Goreau, T.J. 1981. Biogeochemistry of nitrous oxide. Ph.D. diss. Harvard Univ., Cambridge, MA. (Diss. Abstr. 82-22633)

Gosz, J.R., G.E. Likens, and F.H. Bormann. 1972. Nutrient content of litter fall on the Hubbard Brook Experimental Forest, New Hampshire. Ecology 53:769-784.

Grigal, D.F., and L.F. Ohmann. 1992. Carbon storage in upland forests of the Lake States. Soil Sci. Soc. Am. J. 56:935-943.

Groffman, P.M., and J.M. Tiedje. 1989. Denitrification in north temperate forest soils: Spatial and temporal patterns at the landscape and seasonal scales. Soil Biol. Biochem. 21:613-620.

Harris, M.M., and S.J. Rhia. 1991. Carbon and nitrogen dynamics in forest floor during short-term laboratory incubations. Soil Biol. Biochem. 23:1035-1041.

Juma, N.G., E.A. Paul, and B. Mary. 1984. Kinetic analysis of net nitrogen mineralization in soil. Soil Sci. Soc. Am. J. 48:753757.

Keeney, D.R. 1980. Prediction of soil nitrogen availability in forest ecosystems: A literature review. For. Sci. 26:159-171.

Mack, A.R. 1963. Biological activity and mineralization of nitrogen in three soils as induced by freezing and drying. Can. J. Soil Sci. 43:316-324

MacLean, D.A., and R.W. Wein. 1978a. Litter production and forest floor nutrient dynamics in pine and hardwood stands of New Brunswick, Canada, Holarctic Ecol. 1:1-5.

MacLean, D.A., and R.W. Wein. 1978b. Weight loss and nutrient changes in decomposing Iitter and forest floor material in New Brunswick forest stands. Can. J. Bot. 56:2730-2749.

McClaugherty, C.A., J. Pastor, J.D. Aber, and J.M. Melillo. 1985. Forest litter decomposition in relation to soil nitrogen dynamics and litter quality. Ecology 66266-275.

Minderman, G., and J.C. Vulto. 1973. Comparison of techniques for the measurement of carbon dioxide evolution from soil. Pedobiologia 13:73-80.

Mladenoff, D.J. 1987. Dynamics of nitrogen mineralization and nitrification in hemlock and hardwood treefall gaps. Ecology 68:1171-1180.

Moorhead, K.K., D.A. Graetz, and R.K. Reddy. 1987. Decomposition of fresh and anaerobically digested plant biomass in soil. J. Environ. Qual. 16:25-28.

Nadelhoffer, K.J., J.D. Aber, and J.M. Melillo. 1983. Leaf-litter production and soil organic matter dynamics along a nitrogenavailability gradient in southern Wisconsin (USA). Can. J. For. Res. 13:12-21.

Nadelhoffer, K.J. 1990. Microlysimeter for measuring nitrogen mineralization and microbial respiration in aerobic soil incubations. Soil Sci. Soc. Am. J. 30:411-415.

Ohmann, L.F., D.F. Grigal, and S. Brovold. 1989. Physical characteristics of study plots across a Lake States acidic deposition gradient. U.S. For. Serv, Resour. Bull. NC-110. N. Central For. Exp. Stn., St. Paul, MN.

Parkin, T.B., H.R. Kasper, A.J. Sexstone, and J.M. Tiedje. 1984. A gas-flow soil core method to measure field denitrification rates. Soil Biol Biochem. 16:323-330.

Parton, W.J., D.S. Schimel, C.V. Cole, and D.S. Ojima. 1987. Analysis of factors controlling soil organic matter levels in Great Plains grasslands. Soil Sci. Soc. Am. J. 51:1173-1179.
Pastor, J., J.D. Aber, C.A. McClaugherty, and J.M. Melillo. 1984. Aboveground production and $\mathrm{N}$ and $\mathrm{P}$ cycling along a nitrogen mineralization gradient on Blackhawk Island, Wisconsin. Ecology 65:256-268.

Perala, D.A., and D.H. Alban. 1982. Biomass, nutrient distribution and litterfall in Populus, Pinus, and Picea stands on two different soils in Minnesota. Flant Soil 64:177-192.

Plymale, A.E., R.E.J. Boerner, and T.J. Logan. 1987. Relative nitrogen mineralization and nitrification in soil of two contrasting hardwood forests: Effects of site microclimate and initial soil chemistry. For. Ecol. Manage. 21:21-36.

Pregitzer, K.S., and A.J. Burton. 1991. Sugar maple seed production and nitrogen in litterfall. Can. J. For. Res. 21:11481153.

Raich, J.W., and K.J. Nadelhoffer. 1989. Belowground carbon allocation in forest ecosystems: Global trends. Ecology 70:13461354.

Raich, J.W., and W.H. Schlesinger. 1992. The global carbon dioxide flux in soil respiration and its relationship to vegetation and climate. Tellus 44:81-99.

SAS Institute. 1988. SAS/STAT guide for personal computers. Version 6 ed. SAS Inst., Cary, NC.

Schlentner, R.E., and K. Van Cleve. 1985. Relationships between $\mathrm{CO}_{2}$ evolution from soil, substrate temperature, and substrate moisture in four mature forest types in interior Alaska. Can. J. For. Res, 15:97-106.

Schlesinger, W.H. 1977. Carbon balance in terrestrial detritus. Annu. Rev. Ecol. Syst. 8:51-81.

Smith, C.W. 1978. Bayes least significant difference: A review and comparison. Agron. J. 70:23-127.

Smith, J.L., and E.A. Paul. 1990. The significance of soil microbial biomass estimations. p. 357-393. In J. Bollag and G. Stotsky (ed.) Soil biochemistry. Marcel Dekker, New York.

Soulides, D.A., and F.E. Allison. 1961. Effect of drying and freezing soils on carbon dioxide production, available mineral nutrients, aggregation, and bacterial population. Soil Sci. 91;291298.

Sprugel, D.G. 1984. Density, biomass, productivity and nutrientcycling changes during stand development in wave-regenerated balsam fir forests. Ecol. Monogr. 54:165-186.

Stanford, G., and S.J. Smith. 1972. Nitrogen mineralization potentials of soils. Soil Sci. Soc. Am. Proc. 36:465-472.

Stanford, G., M.H. Frere, and D.E. Schwaniger. 1973. Temperature coefficients of soil nitrogen mineralization. Soil Sci. 115:321-323.

Tappeiner, J.C., and A.A. Alm. 1975. Undergrowth vegetation effects on the nutrient content of litterfall and soil in red pine and birch stands in northern Minnesota. Ecology 56:1193-1200.

Weber, M.G. 1985. Forest soil respiration in eastern Ontario jack pine ecosystems. Can. J. For. Res. 5:1069-1073.

Weber, M.G. 1987. Decomposition, litterfall, and forest floor nutrient dynamics in relation to fire in eastern Ontario jack pine ecosystems. Can. J. For. Res. 17:496-506.

Weber, M.G. 1990a. Forest soil respiration after cutting and burning in immature aspen ecosystems. For. Ecol. Manage. 31:114.

Weber, M.G. 1990b. Selected ecosystem processes in a Pinus resinosa Ait. forest in relation to other fire-affected eastern North American forest ecosystems. p. 137-156. In J.G. Goldhammer and M.J. Jenkins (ed.) Fire in ecosystem dynamics, SPB Academic Publ., The Hague.

Zak, D.R., and D.F. Grigal. 1991. Nitrogen mineralization, nitrification and denitrification in upland and wetland ecosystems. Oecologia 88:189-196.

Zak, D.R., G.E. Host, and K.S. Pregitzer. 1989. Regional variability in nitrogen mineralization, nitrification, and overstory biomass in northern Lower Michigan. Can. J. For. Res. 19:15211526.

Zak, D.R., A.B. Hairston, and D.F. Grigal. 1991. Topographic influences on nitrogen cycling within an upland pin oak ecosystem. For. Sci. 37:45-53.

Zak, D.R., and K.S. Pregitzer. 1990. Spatial and temporal variability of nitrogen cycling in northern Lower Michigan. For. Sci. 36:367-380

Zak, D.R., K.S. Pregitzer, and G.E. Host. 1986. Landscape variation in nitrogen mineralization and nitrification. Can. J. For. Res. 16:1258-1263. 